\title{
Analisis dan Implementasi Metode Gabor Filter dan Support Vector Machine pada Klasifikasi Sidik Jari
}

\author{
Intan Raharni Wijaya ${ }^{\# 1}$, Untari Novia Wisesty ${ }^{* 2}$, Said Al Faraby ${ }^{\# 3}$ \\ \# Prodi S1 Ilmu Komputasi, Fakultas Informatika, Universitas Telkom \\ Jl. Telekomunikasi Terusan Buah Batu Bandung 40257 Indonesia \\ ${ }^{1}$ intanraharni@students.telkomuniversity.ac.id \\ ${ }^{3}$ untarinw@telkomuniversity.ac.id \\ 2 saidalfaraby@telkomuniversity.ac.id
}

\begin{abstract}
Identity is the most important thing for identification process. Identification processes that are increasingly vulnerable to hacking require secure system input. Biometrics is a solution for input identification systems that are not vulnerable to hacking. one type of biometric input is a fingerprint because it is unique to each individual and does not change over time. Fingerprint identification system can be done by classification. The classification in this study uses the Gabor filter method with four orientation angles that range from $0^{\circ}, \mathbf{4 5}^{\circ}, \mathbf{9 0}^{\circ}$ and $135^{\circ}$ as fingerprint feature extraction, and Support Vector Machine (SVM) one against all as classifier. With 25 classes and 3 data per fingerprint class obtained the greatest accuracy by radial Basis Function (RBF) kernel for $\mathbf{7 3} \%$ for initial data and $\mathbf{7 6} \%$ for additions augmentation data. The difference in accuracy is due to the possibility of more data position changes in the augmented fingerprint image.
\end{abstract}

Keywords: Biometrics, Fingerprint, Support Vector Machine, Gabor Filter

\begin{abstract}
Abstrak
Identitas merupakan hal utama pada proses identifikasi. Proses identifikasi yang semakin rentan dengan peretasan membutuhkan masukan sistem yang aman. biometrik adalah solusi untuk masukan sistem identifikasi yang tidak rentan peretasan. Salah satu jenis masukan biometri adalah sidik jari karena sifatnya yang unik setiap individu dan tidak berubah seiring waktu. Sistem identifikasi dengan sidik jari dapat dilakukan dengan klasifikasi. Klasifikasi pada penelitian ini menggunakan metode Gabor filter dengan empat sudut orientasi yang berkisar $0^{\circ}, 45^{\circ}, \mathbf{9 0}^{\circ}$ dan $135^{\circ}$ sebagai ekstraksi ciri sidik jari, serta Support Vector Machine (SVM) one against all sebagai classifier. Dengan 25 kelas dan 3 data tiap kelas sidik jari diperoleh akurasi terbesar oleh kernel Radial Basis Function (RBF) sebesar $\mathbf{7 3 \%}$ untuk data awal dan $\mathbf{7 6} \%$ untuk penambahan data augmentasi. Perbedaan akurasi disebabkan oleh kemungkinan perubahan posisi data yang lebih banyak pada citra sidik jari yang diaugmentasi.
\end{abstract}

Kata Kunci: Sistem Biometri, Sidik Jari, Support Vector Machine, Gabor Filter

\section{PENDAHULUAN}

DENTITAS merupakan unsur penting bagi setiap orang yang sering dipakai dalam kebutuhan seharihari. Proses pengenalan identifikasi secara umum identifikasi terbagi menjadi dua cara yakni berdasarkan benda kepemilikan seperti kartu identitas (ATM, KTP, SIM, dan lainnya) dan berdasarkan bagian 
INTAN RAHARNi WiJAYA ET.AL.

fisik yang ada pada diri kita. Seiring dengan perkembangan teknologi, proses identifikasi menggunakan benda memperlihatkan kelemahan dengan rentannya penyadapan dikarenakan benda tersebut dapat hilang, dicuri, ditiru dan masih banyak kemungkinan lain. Sebaliknya, proses identifikasi menggunakan ciri fisik semakin diminati karena unik dan tidak rentan terhadap penyadapan [1].

Jenis identifikasi yang paling sering digunakan adalah identifikasi sidik jari. Sidik jari merupakan aluralur pada ujung jari manusia yang berbeda-beda untuk setiap individu [2]. Sidik jari manusia memiliki sifat yang tidak akan mengalami perubahan bentuk sejak lahir sehingga memudahkan identifikasi. Klasifikasi sidik jari sudah menjadi perbincangan menarik sejak tahun 1975 dan terus berkembang hingga sekarang [3]. Klasifikasi merupakan pemberian label kelas terhadap suatu benda berdasarkan masukan berupa karakter dari fitur benda baik itu secara numerik maupun nominal. Pada sistem klasifikasi sidik jari, sering kali citra tidak terdeteksi dikarenakan masukan citra rusak seperti kotor, terpotong, ataupun posisi sidik jari yang miring. Permasalahan ini disebabkan oleh kesalahan manusia (human error) pada saat pengambilan citra sidik jari.

Ciri pada sidik jari umumnya merupakan jumlah dan posisi guratan-guratan pada sidik jari yang biasa disebut sebagai minutiae. Citra sidik jari yang rusak menyebabkan kerusakan pada ciri yang akan mengurangi kinerja saat ekstrasi ciri maupun klasifikasi yang mengakibatkan citra tidak dapat dikenali. Salah satu pendekatan pada ekstraksi ciri sidik jari dalam menangani citra rusak adalah dengan filter. Pendekatan menggunakan filter pertama diimplementasikan oleh Mehtre (1993) dengan perbaikan citra sidik jari berbasis directional filter [4]. penggunaan filter terus berkembang hingga ditemukan metode Gabor oleh Hong (1998) untuk perbaikan citra sidik jari dengan hasil yang baik [5]. Penggunaan metode filter gabor diminati oleh beberapa riset seperti oleh Youssef (2012) untuk mengekstraksi ciri dalam klasifikasi sidik jari yang menghasilkan kinerja sebesar 94.7\% [6].

Dalam teknik klasifikasi pada sidik jari, metode Support Vector Machine (SVM) digunakan karena dapat melakukan pembelajaran secara tersebar. Arsitektur ini dapat memanfaatkan informasi struktural pada data yang membantu dalam membedakan kelas-kelas tertentu. Metode SVM juga memberikan kinerja tinggi seperti pada riset oleh Ching Tang dan Chia Shing (2014) menghasilkan error rate sebesar 0.5\% [7]. Pada penelitian ini terdapat citra sidik jari yang memiliki posisi pengambilan tidak stabil akibat human error. Dalam mengatasi citra tersebut digunakan klasifikasi SVM dan filter gabor karena dapat digunakan dalam pengambilan ciri tanpa mempedulikan letak minutiae

\section{STUDI LITERATUR}

1) Filter Gabor

Filter gabor didefinisikan oleh fungsi harmonik yang dimodulasi oleh distribusi Gaussian. Filter Gabor bekerja sebagai filter bandpass untuk distribusi frekuensi spasial lokal, mencapai resolusi optimal dalam domain baik spasial dan frekuensi [7]. Berikut persamaan dari filter Gabor:

$$
\begin{gathered}
G(x, y, \theta, \sigma, \lambda)=\exp \left\{-\frac{1}{2}\left[\frac{x_{\theta}^{2}}{\sigma_{x}^{2}}-\frac{x_{\theta}^{2}}{\sigma_{y}^{2}}\right]\right\} \cos \left(2 \pi \frac{x_{\theta}}{\lambda}\right) \\
x_{\theta}=x \cos \theta+y \sin \theta \\
y_{\theta}=-x \sin \theta+y \cos \theta
\end{gathered}
$$

Dimana $\theta$ adalah orientasi gabor filter, $\lambda$ adalah panjang gelombang dari faktor sinusiodal, $\sigma_{x}$ dan $\sigma_{y}$ adalah standar deviasi sifat gaussian sepanjang sumbu $x$ dan $y, x_{\theta}$ dan $y_{\theta}$ mendefinisikan sumbu dan dari koordinat filter.

2) Support vector Machine

Support Vector Machine (SVM) pertama kali diperkenalkan oleh Vapnik pada tahun 1992 sebagai rangkaian harmonis konsep-konsep unggulan dalam bidang pattern recognition [8]. SVM merupakan metode berbasis machine learning yang diangkat sebagai solusi ataupun modifikasi metode sebelumnya yakni metode Neural Networks (NN). Konsep awal SVM merupakan binary classification 
yakni klasifikasi terhadap dua kelas. SVM bekerja atas prinsip Structural Risk Minimization (SRM) dengan tujuan menemukan hyperplane terbaik yang memisahkan dua buah class pada input space [9].

\section{METODOLOGI PENDAHULUAN}

Pada penelitian ini dibangun sistem yang dapat mengklasifikasi data sidik jari berdasarkan ciri yang dibangun dengan filter. Keluaran akhir dari sistem yang dirancang ini adalah identifikasi citra sidik jari pada citra uji. Brikut merupakan alur sistem yang ditampilkan pada flowchart sistem

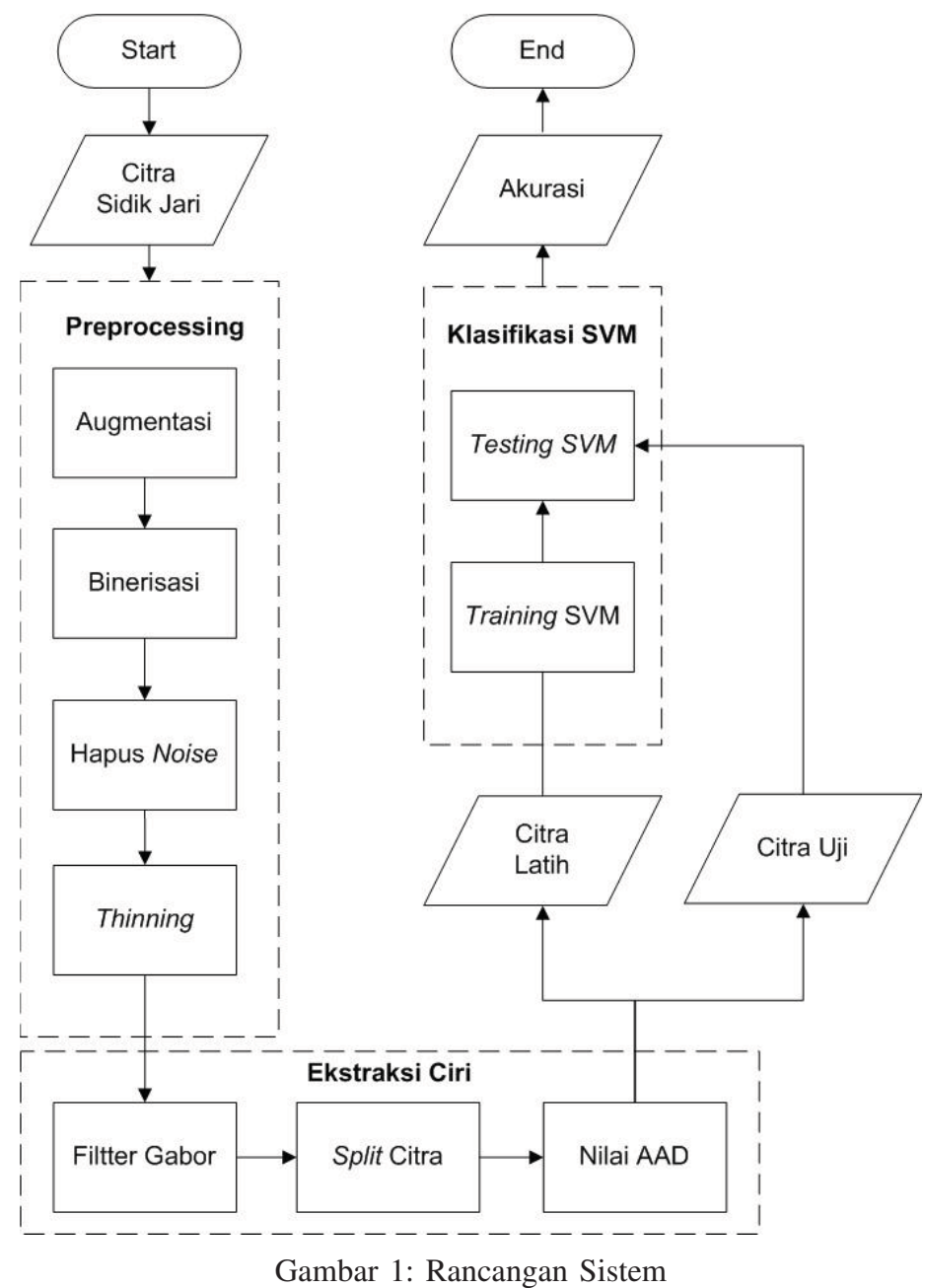

1) Masukan Sistem

Masukan pada sistem ini berupa citra sidik jari yang diperoleh dari data karyawan bandra Soekarno Hatta dengan pengambilan citra jempol kanan sebanyak tiga kali. Citra yang digunakan berukuran 330 X260 piksel. Citra tersebut akan mengalami proses preprocessing terlebih dahulu sebelum dilakukan ekstrasi ciri dan klasifikasi. 
INTAN RAHARNi WiJAYA ET.AL.

2) Augmentasi Citra

Augmentasi bertujuan untuk memperbanyak jumlah data uji dengan pembuatan citra baru berdasarkan citra awal. Dilakukan augmentasi dengan rotasi 5 derajat searah dan berlawanan jarum jam, translasi 10 piksel ke kiri dan kanan serta translasi 10 piksel ke atas dan bawah.

3) Binerisasi

Binerisasi untuk mengasilkan citra dengan nilai 0 dan 1. Proses ini dilakukan utnuk memisahkan antara ciri sidik jari dengan latar.

4) Hapus Noise

Proses penghapusan noise bertujuan untuk memperbaiki kualitas citra dengan cara menghapus objek-objek kecil pada citra yang memiliki kurang dari 50 piksel setelah proses binerisasi.

5) Thinning

Proses thinning bertujuan untuk memperjelas guratan sidik jari menjadi garis-garis setelah proses penghapusan objek.

Berikut merupakan hasil preprocessing sistem pada citra sidik jari pada gambar 2:

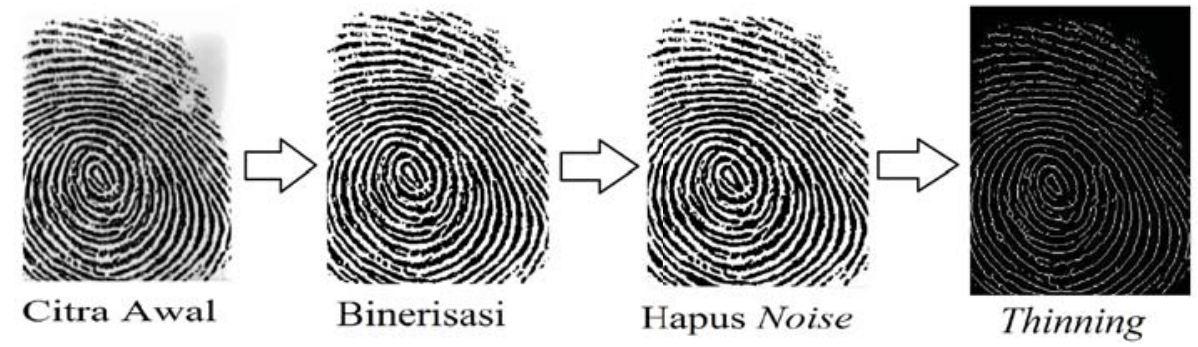

Gambar 2: Tahap Preprocessing

6) Ekstraksi Ciri Filter Gabor Filter Gabor merupakan proses perbaikan citra dengan cara menonjolkan ciri dari suatu citra berdasarkan orientasi derajat gabor. Pada penelitian kali ini terdapat dua parameter utama gabor yang diterapkan yakni:

a) Wavelength $(\lambda)$

Wavelength $(\lambda)$ atau panjang gelombang sinusoid akan mempengaruhi lebar dari ciri yang akan ditampilkan. Semakin besar nilai $(\lambda)$ semakin lebar ciri yang didapat. Sebaliknya, semakin kecil nilai $(\lambda)$ semakin sempit/kecil ciri yang dihasilkan. Pada penelitian ini digunakan $(\lambda)=4$ sepaerti yang dilakukan oleh penelitian hong1998fingerprint.

b) Oriestasi sudut $(\theta)$

Oriestasi sudut $(\theta)$ akan mengontrol perputaran ciri dari filter gabor. secara umum terdapt empat buah sudut $(\theta)$ yakni, sudut $0^{0}, 45^{0}, 90^{\circ}$ dan $135^{0}$ [5].

Berikut merupakan hasil sistem pada citra setelah penggunaan filter gabor pada gambar 3.

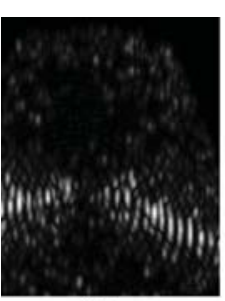

(a)

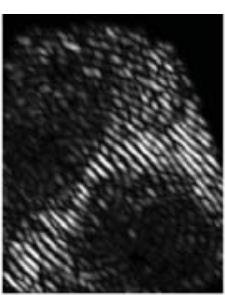

(b)

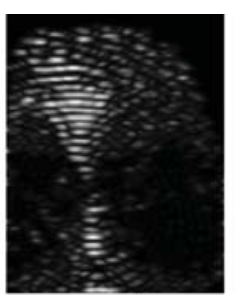

(c)

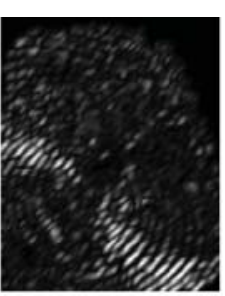

(d)

Gambar 3: Citra Hasil Filter Gabor, (a) Gabor $0^{\circ}$, (b) Gabor $45^{\circ}$, (c) Gabor $90^{0}$ dan (d) Gabor $135^{\circ}$.

7) Split Citra

Proses Split atau pembagian Citra bertujuan untuk membagi-bagi citra yang sudah dilakukan proses filter yang nantinya akan dilakukan ekstraksi ciri dengan Absolute Average Deviation berdasarkan 
nilai mean atau rata-rata dari masing-masing sektor citra. Pada penelitian kali ini, Citra berukuran 330x260 piksel dibagi menjadi dua split yakni:

a) Pembagian ukuran citra 3x3, citra awal berukuran 330x260 dengan 4 sudut filter gabor menjadi 36 bagian citra dengan ukuran $110 \times 87$ piksel setiap bagian.

b) Pembagian ukuran citra 5x5, citra awal berukuran 330x260 dengan sudut filter gabor menjadi 100 bagian citra dengan ukuran 66x52 piksel setiap bagian.

Berikut merupakan pembagian citra sidik jari hasil filter tertera pada gambar 4

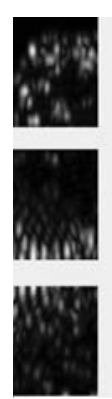

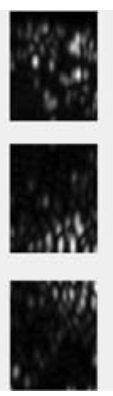

(a)

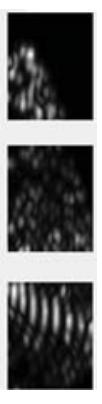

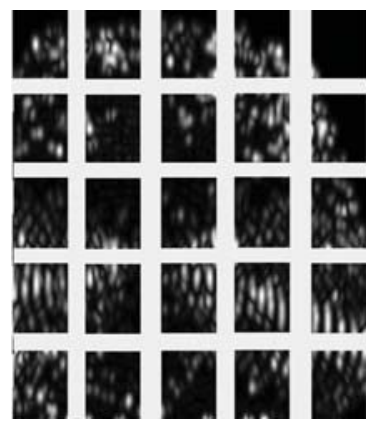

(b)

Gambar 4: Split Citra pada Hasil Filter Gabor $0^{0}$, (a) Split Citra 3x3 (b) Split 5x5.

8) Perhitungan nilai Absolute Average Deviation (AAD)

Pada penelitian ini ciri yang digunaka sebagain masukan kalsifikasi adalah dengan Absolute Average Deviation (AAD) atau simpangan rerata dari setiap sektor split citra. Nilai AAD didapat dari persamaan berikut:

$$
V_{i \theta}=\frac{1}{n_{i}}\left(\sum_{n_{i}}\left|F_{i \theta}(x, y)-P_{i}^{\theta}\right|\right)
$$

Dengan $n_{i}$ merupakan total piksel sektor ke-i, $F_{i}(x, y)$ merupakan hasil filtering pada arah $\theta$ untuk setiap sektor split Si. $V_{i \theta}$ merupakan Absolute Average Deviation (AAD) dari rata-rata piksel sektor $\left(P_{i \theta}\right)$.

Dalam penelitian ini digunakan pembagian sektor $3 \times 3$ dan $5 \times 5$ serta penerapan 4 sudut orientasi gabor. Sehingga ukuran ciri yang terbentu adalah split $3 \times 3 \times$ jumlah orientasi filter + split5x $5 x$ jumlah orientasi filter $=(9 \times 4)+(25 \times 4)=136$ ciri. Hasil yang diperoleh dari proses pencarian nilai AAD merupakan matriks ciri berukuran 1x136 bagi setiap citra yang selanjutkan akan dilakukan tahap klasifikasi SVM.

9) Klasifikasi SVM

Klasifikasidengan menggunakan SVM One Against All terbagi menjadi dua tahap yakni training dan testing:

a) Training citra dengan metode SVM bertujuan untuk mendapatkan model SVM dengan variable $\alpha, w, b$ dan $x_{\text {sup }}$ (data yang merupakan support vector. Masukan pada sistem untuk training adalah Data ciri sidik jari yang didapat hasil perhitungan AAD pada citra yang diberi filter Gabor. Data terbagi menjadi data train dan data tes. Selain itu terdapat $y_{\text {train }}$ (kelas dari data train) dan $y_{\text {target }}$ (kelas dari data tes) untuk masukan sistem.

b) Testing

Model yang didapat saat training SVM digunakan untuk data uji yakni citra ke tiga dari masing-masing kelas (orang). Hasil dari proses testing adalah $y_{\text {prediksi }}$ yang nantinya akan dicocokkan dengan $y_{\text {target }}$. Berikut adalah contoh pengujian data tes menggunakan metode SVM one against all dengan catatan jika bernilai positif lebih dari satu kelas maka data tersebut tidak dikenali kelasnya. 
INTAN RAHARNi WiJAYA ET.AL.

10) Skenario Pada penelitian ini terdapat 3 skenario pengujian untuk masing-masing nilai skalar pada image brightness 3 dan 4:

a) Skenario 1

Pada skenario 1 pengujian dilakukan dengan menggunakan data latih dari citra asli yang berjumlah 180 citra latih dengan mengubah-ubah jumlah kelas setiap pengujiannya. Jumlah kelas yang digunakan adalah 5, 10, 15, 20 dan 25 kelas. Pengujian menggunakan SVM dengan kernel linear. Pengujian bertujuan untuk membandingkan akurasi sistem sesuai dengan penambahan kelas data.

b) Skenario 2

Pada skenario 2 pengujian dilakukan dengan menambah dua kernel SVM (RBF, dan polynomial) pada kriteria pengujian skenario 1. Nilai parameter sigma $(\sigma)$ yang digunakan adalah 2, 4, 6 s.d 20 sedangkan nilai parameter yang digunakan untuk derajat polynomial adalah 1, 2, 3, 4 dan 5. Pengujian ini bertujuan untuk membandingkan akurasi sistem berdasarkan perbedaan kernel SVM.

c) Skenario 3

pengujian dilakukan dengan menggunakan data latih dari citra asli dan citra augmentasi. Pengujian dengan penambahan citra augmentasi pada data training bertujuan untuk meningkatkan akurasi dengan memperbanyak kemungkinan perubahan bentuk citra agar membantu proses latih SVM. Pengujian menggunakan 25 kelas. Hasil yang dibandingkan adalah kemampuan data citra augmentasi pada akurasi sistem.

d) Skenario 4

Pada skenario 4 dilakukan dengan membandingkan hasil sistem terhadap pengaruh jumlah ciri. Ciri yang dipakai berjumlah 36, 100 dan 136. Pengujian dilakukan dengan menggunakan 25 kelas. Pengujian bertujuan untuk mencari jumlah ciri terbaik berdasarkan akurasi.

\section{HASIL DAN PEMBAHASAN}

1) Skenario 1 Perubahan Jumlah Kelas

Hasil yang dicapai sistem seperti yang tertera pada grafik 6 menunjukkan bahwa akurasi sistem tertinggi diperoleh oleh 5 kelas data dan terjadinya penurunan akurasi seiring dengan bertambahnya jumlah kelas pada data. Hal ini disebabkan karena semakin banyak jumlah kelas yang dipakai maka semakin kecil jarak margin antara hyperplane dan support vector sehingga sulit untuk memisahkan data antar kelas. Hasil sistem untuk 25 kelas hanya sebesar $68 \%$, 67\% dan 68\% sedangkan untuk 5 kelas diperoleh $100 \%$. Maka, dapat diasumsikan bahwa data hasil ekstraksi ciri yang didapat bisa terklasifikasi.

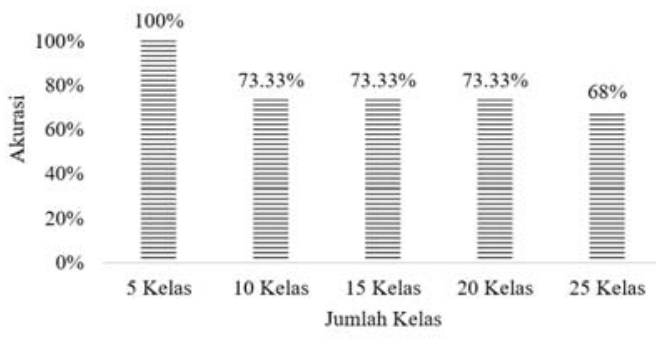

(a)

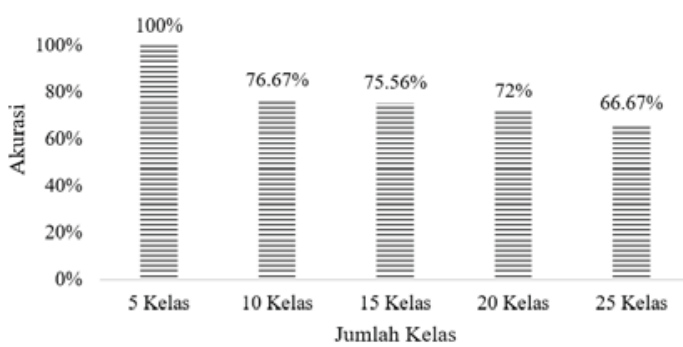

(b) 


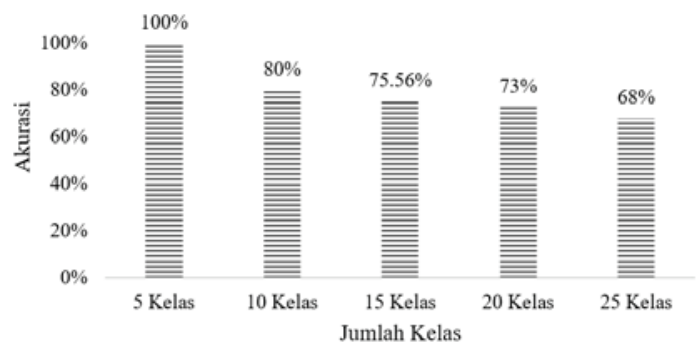

Gambar 6: Hasil Akurasi terhadap Perbandingan Jumlah Kelas dengan Kernel Linier Menngunakan (a) 36 Ciri, (b) 100 Ciri, dan (c) 136 Ciri.

2) Skenario 2 Perubahan Kernel SVM

Hasil pengujian membuktikan bahwa kerne RBF memeberikan akurasi tertinggi untuk masingmasing jumlah ciri (36, 100 dan 136). Hal ini dikarenakan kernel RBF memberikan hyperplane dengan jarak margin terbesar terhadap data support vector dibandingkan kedua kernel lainnya. Pada grafik 7 terlihat perbedaan akurasi untuk kernel linear dan kernel RBF serta polynomial memiliki perbedaan yang tidak signifikan. Sehingga dapat diasumsikan data sidik jari sistem berdasarkan filter gabor dan perhitungan nilai AAD merupakan data lineary separable data atau data yang masih bisa terpisah secara linier.

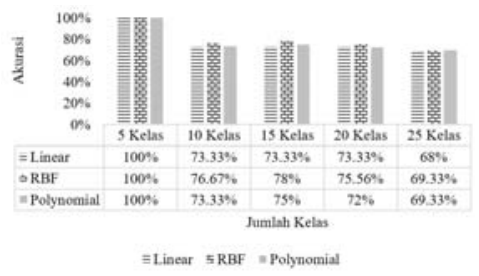

(a)

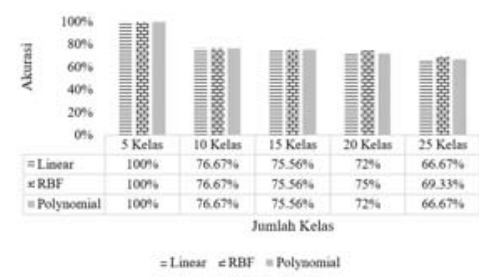

(b)

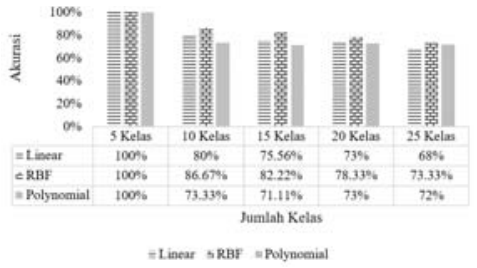

(c)

Gambar 7: Hasil Akurasi terhadap Perbandingan Tiga Jenis Kernel SVM dengan Kernel Linier Menggunakan (a) 36 Ciri, (b) 100 Ciri, dan (c) 136 Ciri.

3) Skenario 3 Penambahan Citra Augmentasi

Pada skenario 3 dilakukan pengujian menggunakan data ciri citra sidik jari awal dengan penambahan data citra aumentasi. Data ciri diperoleh berdasarkan penggunaan Filter Gabor dan perhitungan nilai AAD. Pengujian sistem dengan tiga jenis kernel dan perubahan parameter seperti pada skenario 1. Hasil pengujian sistem terdapat pada grafik 8 dengan akurasi augmentasi tertinggi masing-masing jumlah ciri sebesar $72 \%, 72 \%$, dan $76 \%$. Jika dibandingkan dengan pengujian pada skenario 1, data ciri citra augmentasi memiliki akurasi lebih tinggi. Hal ini disebabkan oleh penambahan data yang menambah kemungkinan pergerakan citra dan membantu sistem mengenali citra dengan sudut dan posisi yang berbeda. 
INTAN RAHARNi WiJAYA ET.AL.

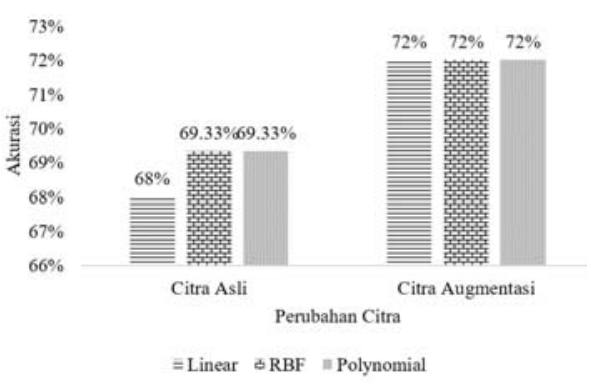

(a)

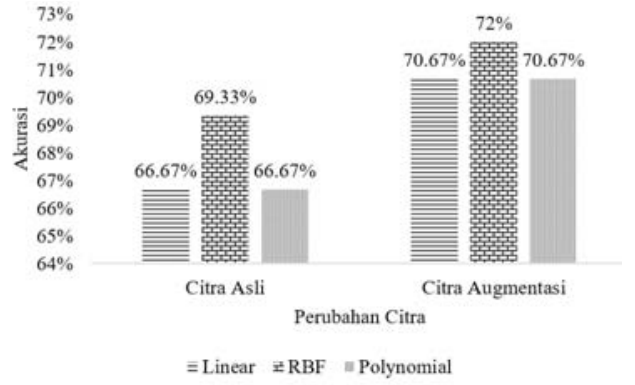

(b)

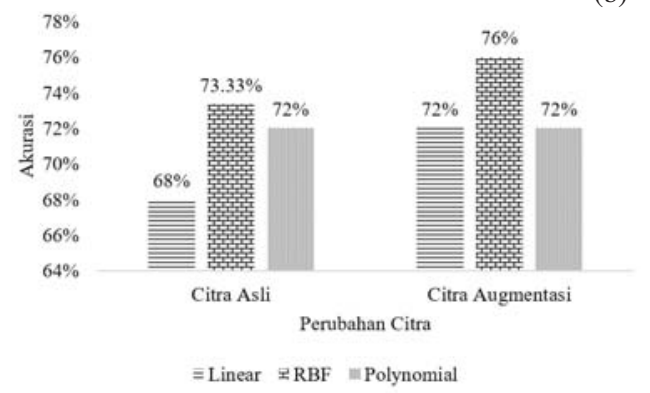

(c)

Gambar 8: Hasil Akurasi terhadap Perbandingan Tiga Jenis Kernel SVM dengan Kernel Linier Menggunakan (a) 36 Ciri, (b) 100 Ciri, dan (c) 136 Ciri.

4) Skenario 4 Perubahan Jumlah Ciri Berdasarkan tiga skenario pengujian diatas, dilakukan perbandingan hasil akurasi sistem untuk penggunaan tiga kernel SVM yakni kernel linear, RBF, dan polynomial untuk 25 kelas data dari citra asli dan citra augmentasi. Pengujian dilakukan dengan membandingkan hasil tiga jenis ciri yang dimiliki yakni 36, 100 dan 136 ciri. Pengujian bertujuan untuk mencari jumlah ciri optimal pada citra. hasil perbandingan terdapat pada grafik 9. Diantara ketiganya hasil akurasi terbaik dimiliki oleh jumlah 136 ciri. Didapat kesimpulan, semakin bertambah jumlah ciri maka semakin tinggi hasil akurasi sistem yang didapat dan kemungkinan data terklasifikasi. Hal ini terjadi karena semakin banyak ciri (fitur) suatu benda ataupun individu maka data akan semakin spesifik dan memudahkan klasifikasi.

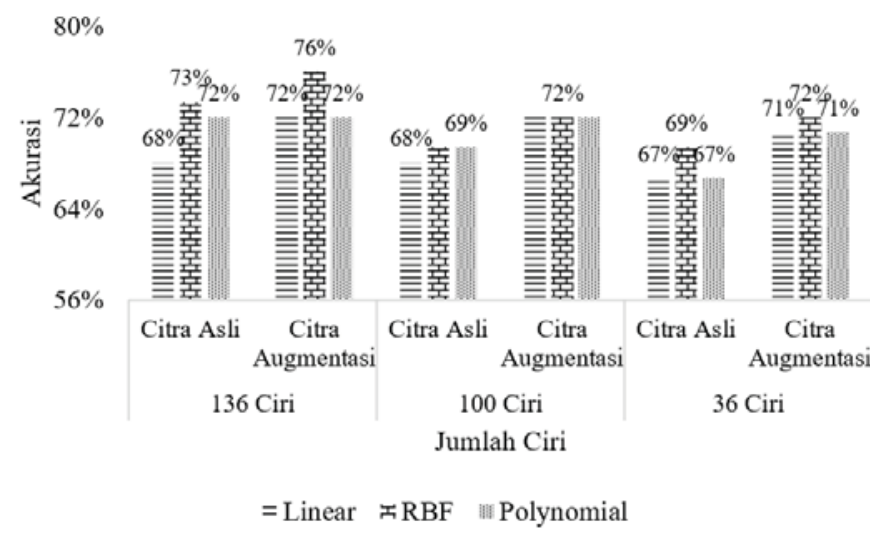

Gambar 9: Perbadingan Akurasi terhadap Seluruh Skenario Uji dengan Tiga Jenis Jumlah Ciri 


\section{KESIMPULAN}

1) Ekstraksi ciri sidik jari menggunakakan filter gabor dan perhitungan nilai AAD menghasilkan ciri yang berjumlah 36, 100 dan 136. Ciri yang memeberikan performansi sistem terbaik adalah dengan 136 ciri hasil dari penggabungan dua jenis split.

2) Perubahan parameter pada kernel RBF dan polynomial berpengaruh pada akurasi sistem. Setiap data memiliki parameter tersendiri. Berdasarkan pengujian, nilai akurasi dengan perubahan parameter akan membuat kurva dengan puncak maksimum akurasi. Perubahan parameter derajat pada kernel polynomial menghasilkan bahwa derajat satu memberikan performasi tertinggi. Serta semakin kecil jumlah ciri maka semakin kecil nilai parameter sigma yang didapat.

3) Penambahan citra Augmentasi pada skenario 3 utnuk masing -masing jumlah ciri (36, 100 dan 136 ciri) berpengaruh pada meneningkatkatnya akurasi sistem. karena semakin banyak data latih maka semakin banyak kemungkinan bentuk data yang memudahkan klasifikasi sistem.

4) Performansi terbaik dari sistem secara keseluruhan adalah dengan perubahan parameter kernel RBF yakni sigma pada skenario 2. Akurasi yang diperoleh sebesar $76 \%$ untuk 25 kelas data citra sidik jari.

\section{PERSEMBAHAN}

Dalam kesempatan ini penulis ingin mengucapkan terimkasih kepada semua pihak yang telah memberikan bantuan, dukungan, semangat, serta doa dalam menyelesaikan paper ini. Dengan segala kerendahan hati, penulis ingin menyampaikan ucapan terima kasih kepada:

1) Allah Subhanahu wa ta'ala yang selalu memberikan kekuatan, kemudahan, dan pecerahan dalam menyusun paper ini.

2) Kedua orangtua dan kedua kakak, Bapak Gunawan Wijaya, Ibu Alis Rini Suryani, Fika Mareta Wijaya S.T, Bhakti Destian Wijaya S.Kom yang selalu memberikan motivasi, semangat, doa dan kasih sayang untuk menyelesaikan paper ini

3) Ibu Untari Novia Wisesty, S.T., M.T. dan Bapak Said Al Faraby, S.T., M.Sc. selaku pembimbing I dan II, atas waktu dan masukan yang diberikan kepada penulis dalam menyelesaikan paper ini.

4) Irba Fairus Thufailah S.Si.Kom dan Patma Oktaviana yang selalu menjadi teman terbaik dikala susah maupun senang. Serta semua pihak yang belum disebutkan oleh penulis, terima kasih atas dukungan semangat dan bantuannya.

\section{PUSTAKA}

[1] James Wayman, Anil Jain, Davide Maltoni, and Dario Maio. An introduction to biometric authentication systems. Biometric Systems, pages 1-20, 2005.

[2] Badiatul Muchlisin Asti and Junaidi Abdul Munif. 105 Tokoh Penemu dan Perintis Dunia. Penerbit Narasi, 2009.

[3] Mikel Galar, Joaquín Derrac, Daniel Peralta, Isaac Triguero, Daniel Paternain, Carlos Lopez-Molina, Salvador García, José M Benítez, Miguel Pagola, Edurne Barrenechea, et al. A survey of fingerprint classification part i: taxonomies on feature extraction methods and learning models ], part ii: experimental analysis and ensemble proposal. Knowledge-based systems, 81:76-116, 2015.

[4] Babu M Mehtre. Fingerprint image analysis for automatic identification. Machine Vision and Applications, 6(2-3):124-139, 1993.

[5] Lin Hong, Yifei Wan, and Anil Jain. Fingerprint image enhancement: Algorithm and performance evaluation. IEEE transactions on pattern analysis and machine intelligence, 20(8):777-789, 1998.

[6] Youssef Elmir, Zakaria Elberrichi, and Reda Adjoudj. Support vector machine based fingerprint identification. In Ctci 2012 Conference, 2012.

[7] Ching-Tang Hsieh and Chia-Shing Hu. Fingerprint recognition by multi-objective optimization pso hybrid with svm. Journal of applied research and technology, 12(6):1014-1024, 2014.

[8] S Sathiya Keerthi and Chih-Jen Lin. Asymptotic behaviors of support vector machines with gaussian kernel. Neural computation, 15(7):1667-1689, 2003.

[9] Krisantus Sembiring. Tutorial svm bahasa indonesia. Bandung, Teknik Informatika ITB, 2007. 
